\title{
モーダル反復誤差修正法を用いた 弾塑性地盤モデルにおける基盤入力動インバージョン INPUT MOTION INVERSION IN ELASTO-PLASTIC SOIL MODEL
BY USING MODAL ITERATIVE ERROR CORRECTION METHOD
} 鈴木环也*1

Takuya SUZUKI

\begin{abstract}
In conducting simulation analyses, an input motion should be set to reproduce an observed wave at an observed point. If the analysis model is in a linear range, the input motion can easily be set. However, this setting is difficult if the analysis model exhibits non-linear behavior. This study proposes a new time domain inversion method with a generalized inverse of the perturbation impulse matrix and the iterative method. First, the method outline and details are described. Second, the method precision is confirmed through experimentation. Thus, a new method for input motion inversion in a non-linear soil model is presented.
\end{abstract}

Keywords : $\quad$ Input M otion Inversion, Impulse Response, Singular Value Decomposition, Elasto-Plastic soil Model 入力動インバージョン, インパルス応答, 特異值分解, 弾塑性地盤モデル

\section{1. はじめに}

本研究は, 非線形地盤モデル上の任意の 1 点において指定された 波形を再現するための, 入力地震動の設定手法を提案することを目 的とする。

地震後の建物の健全性評価において, 基礎構造など容易に目視観 測を行うことが困難な個所の評価を行う場合, シミュレーション解 析例えば 12)を利用する方法が有効な手法のひとつである。この場合, 解析に用いる入力地震動は, 建物内もしくは周辺で計測された観測 記録に基づき, 解析モデル上の観測位置において観測地震動が再現 できるように設定される必要がある（Fig.1）。

この入力地震動設定の方法として, SHAKE ${ }^{3)}$ や壇の方法 ${ }^{4)}$ に代表 される周波数領域で入力地震動を調整する方法が挙げられる。ただ し, 周波数領域による方法は基本的に解析中地盤の物性值が一定で ある場合にのみ適用可能である。しかしながら，一般的に地震時の 地盤の挙動は逐次非線形性を示し, 地盤の物性值は時々刻々変化す るため, 周波数領域による方法は汎用的に適用することは難しい。

したがって, 地盤の強非線形化が予測され，地盤の非線形特性と して精度の高い逐次非線形モデルを採用した場合, シミュレーショ ン解析に用いる入力地震動の設定には, 時間領域による方法を採用 する必要がある。

時間領域で入力地震動を設定する方法に関する既往の研究として, カルマンフィルターを用いた線形モデルの入力地震動の設定 ${ }^{5) 6)}$, EK-WLI ${ }^{7}$ による絶対加速度を用いた入力地震動およびシステム同

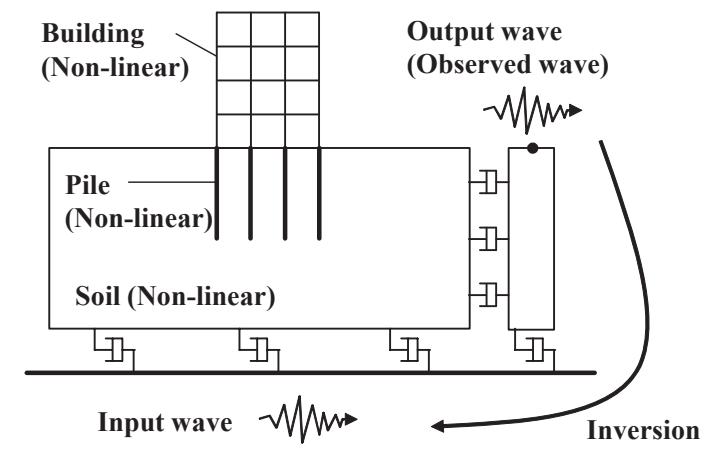

Fig.1 Input Motion Inversion

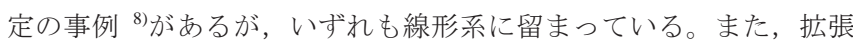
カルマンフィルターを用いて非線形 1 自由度系に対する定式化を行 った事例 9)もあるが, 検証は線形モデルに留まっているほか, 加速 度の再現性は低い。これに対し，非線形を考慮した事例として，基 盤入力地震動を未知数として入力地震動を逆算する手法が示されて いるが，入力波に多くの高振動成分が生じ，適宜ローパスフィルタ 一を掛ける必要がある ${ }^{10)}$ 。また, 解析プログラムの運動方程式の演 算部分の改良が必要であり, 市販の汎用解析プログラムを用いたシ ミュレーション解析に用いるための入力地震動を設定することは難 しい。著者の知る限り, 解析モデルの挙動が逐次非線形性を示す場 
合に, 観測記録等に基づいて入力地震動を時間領域で設定する汎用 的な手法は示されていない。

そこで, 本研究においては, 非線形地盤モデルにおいて入力地震 動を時間領域で設定する新たな手法を提案することを目的とする。 提案手法は，システム同定の一手法であるインパルス応答マトリク スの特異值分解 ${ }^{11}$ を用いて, 有意なモード形状を選択し反復的に誤 差を修正していくことを特徴とする手法 (Modal Iterative Error Correction 法, MIEC 法と称する) である。

なお，精確なシミュレーション解析を実施する上では解析モデル が真の挙動を表現できるように設定されていることが必要不可欠で あるが，本研究においてはこの解析モデルは正しく設定されている ことを前提にして, インバージョンの手法を提案する。

まず，提案手法のフローおよび計算手順について説明する。つづ いて, 例題を用いて提案手法の精度検証を行う。

\section{2. 提案する基礎入力動のインバージョン手法}

\section{1 課題と解決方針}

はじめに, 現状の課題と解決方針を示す。Table1 には, 以降で用 いる主な記号の説明を示す。なお，本報でのベクトルは全て列ベク トルとして扱う。

本手法においては, 有限要素法等の構造解析による演算処理を,

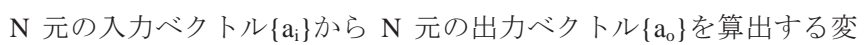
換システム F とみなす。システム F は N X N の演算マトリクスとみ なすこともできる。

$$
\left\{a_{0}\right\}=F\left(\left\{a_{i}\right\}\right)
$$

基礎入力動のインバージョンはこの逆演算, 寸なわち, 出力ベク トル $\left\{a_{0}\right\}$ から入ガクトル $\left\{a_{i}\right\}$ を計算することに相当する。

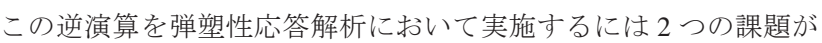
ある。1つは式(1)の演算は順方向に単射変換であるが, 逆方向には 単射変換とはならないこと, もう 1 つは, F が線形システムではな く, 構造解析の演算における弾塑性挙動の度合いに応じて, 寸なわ ち, 入力ベクトル $\left\{\mathrm{a}_{\mathrm{i}}\right\}$ に応じて出力が複雑に変化する非線形システ ムであるということである。

このような課題に対して, 本提案手法では, 弾塑性の構造解析の 求解で用いられる演算マトリクス（式(1)のF）の接線勾配を用いた 反復法を採用寸ることで解決を図る。この演算マトリクスの接線勾 配とは, 入力地震動の微小な変分（摂動）から, 出力の微小変分を 算定するマトリクスに相当する（Fig.2）。本研究ではこのマトリク スを,「摂動インパルス応答マトリクス」と呼ぶ。摂動インパルス応 答マトリクスの各列は, ある時刻において単位摂動を加えた場合の 出力の摂動となる。そのため, このマトリクスの上三角部分は必ず 0 となり, 場合によっては対角部分も 0 となる。本提案手法は, こ の摂動インパルス応答マトリクスの逆行列を用いて, 誤差を解消寸 るような入力攝動を逆算し, 修正を行うことで徐々に収斂解を近似 的に得ることを図るものである。

なお，摂動インパルス応答マトリクスを用いた場合でも，前述し た「逆行列が一意に定まらない」,「マトリクスが時々刻々変化する」, という課題は残る。そこで本手法においては, 前者については, 通 常の逆行列ではなく一般化逆行列 ${ }^{11}$ を用い, かつその主要モードの

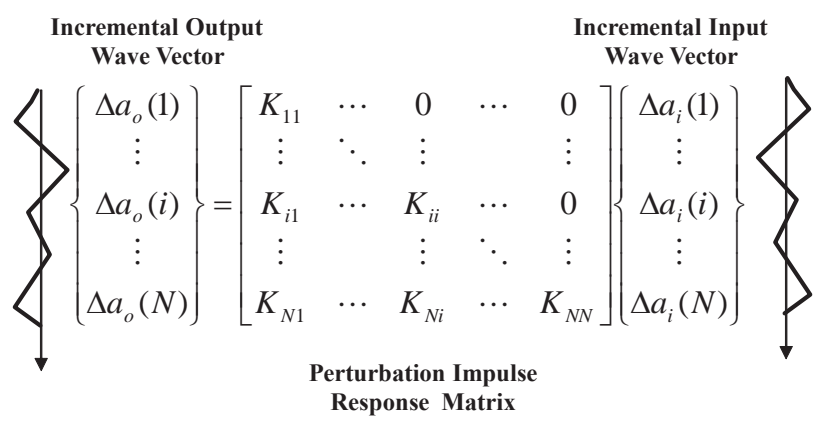

Fig.2 Perturbation Impulse Response Matrix

Table1 Symbol List

\begin{tabular}{|c|c|}
\hline $\mathrm{N}$ & : Number of time steps \\
\hline$\left\{a_{i}\right\}$ & : Input wave vector \\
\hline$\left\{a_{0}\right\}$ & : Output wave vector \\
\hline$\left\{\mathrm{a}_{\mathrm{dum}}\right\}$ & : Dummy imput wave vector \\
\hline$\left\{a_{\text {tar }}\right\}$ & : Target of output wave vector \\
\hline$[\mathrm{K}]$ & : Perturbation impulse matrix \\
\hline$[\mathrm{U}]$ & : Left singular matrix \\
\hline$[\mathrm{V}]$ & : Right singular matrix \\
\hline$[\Sigma]$ & : Singular value matrix \\
\hline $\mathrm{F}(\mathrm{)}$ & : Calc. system by analysis \\
\hline$\left\{\Delta a_{i}^{j}\right\}$ & $: \mathrm{j}^{\text {th }}$ time step perturbation input wave vector \\
\hline$\left\{a_{i}^{j}\right\}$ & : Input wave vector added $\mathrm{j}^{\text {th }}$ time step perturbation \\
\hline$\left\{a_{0}^{j}\right\}$ & : Output wave vector by input added $j^{\text {th }}$ time step perturbation \\
\hline$\left\{\Delta \mathrm{a}_{0}^{j}\right\}$ & : Variation wave vector by $\mathrm{j}^{\text {th }}$ time step perturbation input \\
\hline$\left\{k^{j}\right\}$ & : Variation coef. vector by $\mathrm{j}^{\text {th }}$ time step perturbation input \\
\hline$\Delta$ & : Perturbation magnitude \\
\hline$\varepsilon$ & : Allowable tolerance \\
\hline$\{r\}$ & : Residual error of output wave vector \\
\hline
\end{tabular}

みを用いて修正を行うことで，後者については，摂動インパルス応 答マトリクスを反復のループ毎に求め直すことで解決する。

\section{2 演算手順}

提案手法のフロー図をFig.3 に示す。図に示すように全体的なフ ローは弾塑性の構造解析を陰解法で実施する場合に汎用される N ewton-Raphson 法 ${ }^{12)}$ と類似した形となる。すなわち，ある候補波の 誤差を確認したのち, その誤差を補うための加速度補正量を，「現時 点の誤差量」および，「現在の候補波から各ステップにおいて摂動を 与えた場合の出力に及ぼす影響度合」から算出する。さらに, 修正 された入力地震動を用いて再度精度の確認を実施し, 許容範囲内で あれば修正を終了し，許容範囲外であれば，許容範囲内に同様の方 法で繰り返し加速度を修正していく。以降では, フロー内の各処理 の詳細について述べる。 


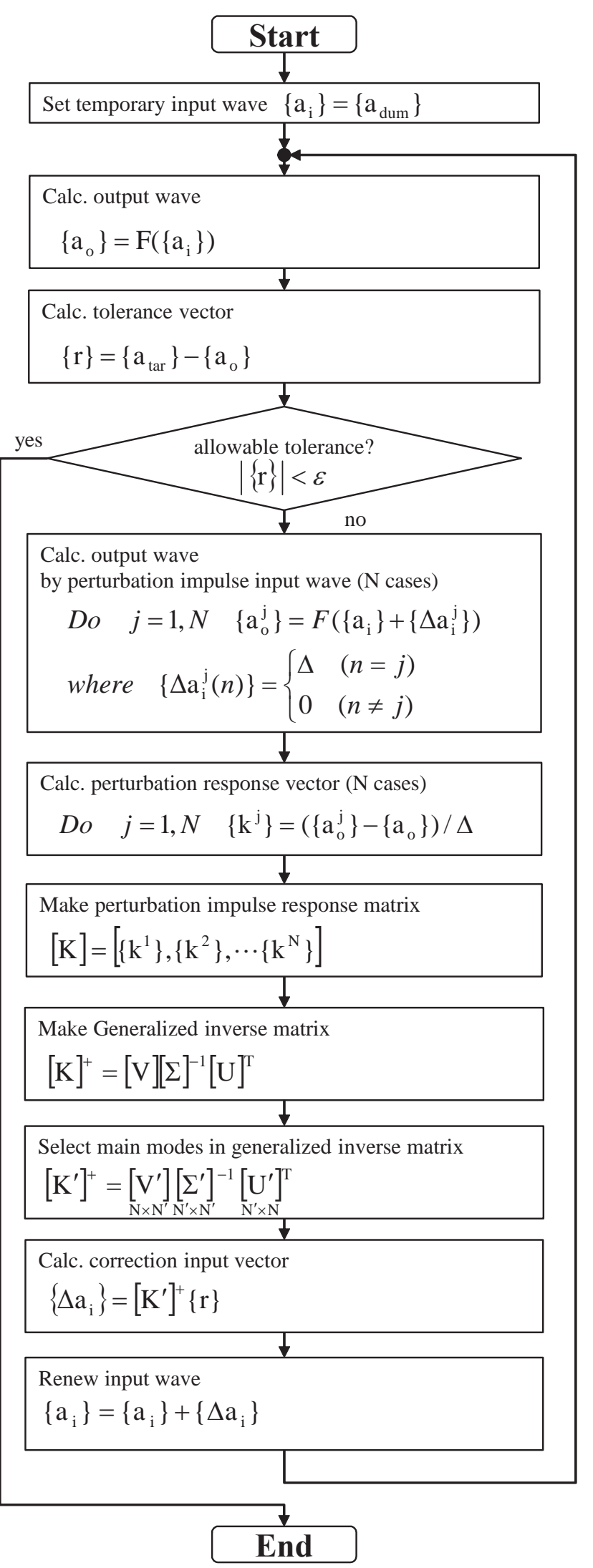

Fig.3 Flow Diagram

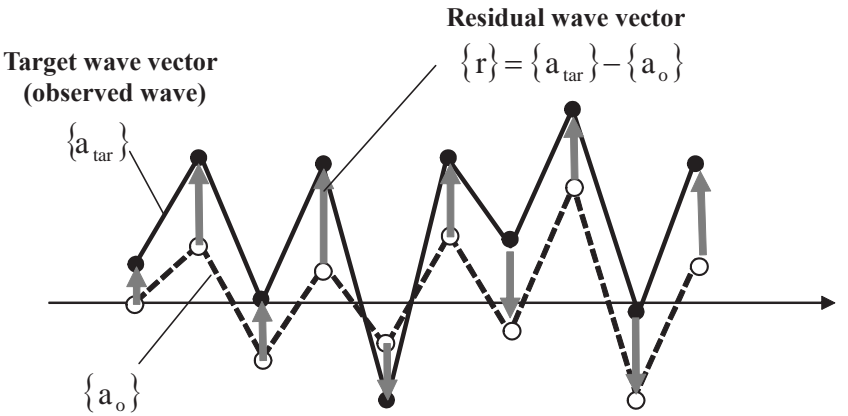

Calculated wave vector

By predicted input wave

Fig.4 Residual wave vector

\section{(a) 候補入力地震動による誤差の確認}

まず，初期の候補入力地震動を設定する。これは，初期剛性を用 いて振動数領域の方法によって求めた入力地震動でも, 入力が完全 に0の地震動でもよいが, 後の収斂計算の回数を減らすためには, 精度の高い初期予測解を用いることは有効である。

$$
\left\{a_{i}\right\}=\left\{a_{\text {dum }}\right\}
$$

この候補に対して, 地震応答解析を実施し, 出力対象点の時刻歴 波形を算出する。

$$
\left\{a_{0}\right\}=F\left(\left\{a_{i}\right\}\right)
$$

つづいて, 得られた出力波形ベクトルと, 観測記録等のターゲッ トとなる出力波形ベクトルの誤差ベクトルを算出する (Fig.4)。

$$
\{r\}=\left\{a_{\operatorname{tar}}\right\}-\left\{a_{0}\right\}
$$

この誤差ベクトルが十分に小さければ，候補入力地震動で十分な 精度を確保できていることになるが，候補入力地震動によってター ゲット波が十分な精度で再現できない場合には誤差が生じる。

そこで, この誤差ベクトルの成分のノルムを抽出し, その值が許 容範囲内であるかを以下の式によって判定し, 許容範囲外であれば, 以降で説明する入力地震動の補正を行う。

$|\{r\}|<\varepsilon$

なお，許容誤差は解析モデルや用途，単位系に応じて適宜設定す る（例えば， $0.01 \mathrm{~cm} / \mathrm{s}^{2}$ など）。また，判定式もノルムによる方法以 外にも，誤差ベクトルの最大成分で判定してもよい。

\section{(b) 摂動インパルス応答マトリクスの作成}

誤差の修正に先立ち，微小な摂動を加えた場合の影響評価解析を 実施する。具体的には, 現時点の候補入力地震動の時間ステップ $\mathrm{n}$ がある時間ステップ $\mathrm{j}$ と一致する時刻の入力に微小の摂動を加えて 応答解析を実施し，摂動を加えた場合の出力波形ベクトルを得る。

$$
\left\{a_{0}^{j}\right\}=F\left(\left\{a_{i}\right\}+\left\{\Delta a_{i}^{j}\right\}\right)
$$

where $\left\{\Delta a_{i}^{j}(n)\right\}= \begin{cases}\Delta & (n=j) \\ 0 & (n \neq j)\end{cases}$ 
ここで微小の摂動量 $\Delta$ はインバージョンによって得られる入力 地震動に求める精度に応じて設定する。例えば, $0.1 \mathrm{~cm} / \mathrm{s}^{2}$ 単位での 精度が必要であれば, 同程度の值を設定することが望ましい。なお, この值は大きすぎれば，収斂の仮定で振動が生じ収斂解が得られな くなる可能性が高くなり, 一方, 小さければ, 収斂に多くの時間を 要することになる。

このある時間ステップの入力に摂動を与えた応答解析を, 全時間 ステップ数分実施することで, $\mathrm{N}$ 個の出力波形ベクトルが得られる。 この出力波形ベクトルと式(3)において求めた出力波形ベクトルの 差分が各ステップでの摂動が出力に与える影響を示している(Fig.5)。 そこで, これを, 与えた摂動量によって無次元化して, 無次元の影 響係数ベクトルに変換する。

$$
\left\{k^{j}\right\}=\left(\left\{a_{0}^{j}\right\}-\left\{a_{0}\right\}\right) / \Delta
$$

さらに，これらの影響係数ベクトルを列ベクトルとして，全ての 影響係数ベクトルを並べることにより，摂動インパルス応答マトリ クス（正方行列 $N \times N ）$ を作成する。

$$
[K]=\left[\left\{k^{1}\right\},\left\{k^{2}\right\}, \cdots,\left\{k^{N}\right\}\right]
$$

この摂動インパルス応答マトリクスは, 現時点で候補となってい る入力ベクトルに微小の増分ベクトル $\left\{\Delta \mathrm{a}_{\mathrm{i}}\right\}$ を与えた場合の出力の 差分ベクトル $\left\{\Delta a_{0}\right\}$ を算定するマトリクスとなっている。

$$
\left\{\Delta \mathrm{a}_{0}\right\}=[\mathrm{K}]\left\{\Delta \mathrm{a}_{\mathrm{i}}\right\}
$$

\section{(c) 䎼動インパルス応答マトリクスの一般化逆行列の作成}

式(10)の左辺が, 式(4)で求めた誤差分と一致するように, $\left\{\Delta \mathrm{a}_{\mathrm{i}}\right\}$ を 探索して入力地震動を補正する。そのためには, 摂動インパルス応 答マトリクスの逆行列を算出する必要がある。しかしながら, 2.1 節で述べたように，このマトリクスは一般的には対角項に值が入ら ないため, 行列のランクがマトリクスのサイズ未満となり, 逆行列 を一意には決定できない。そこで, 特異值分解を用いた一般化逆行 列を作成する。特異值分解は行列分解の一手法であり, 信号処理や 統計学の分野において用いられ, 任意の形の行列を分解, 逆行列の 算定ができることを特徵とする。

摂動インパルス応答マトリクス $[\mathrm{K}]$ の特異值分解を行うことによ り, 行列[K]は以下のように分解される。

$$
[\mathrm{K}]=[\mathrm{U}][\Sigma][\mathrm{V}]^{\top}
$$

ここで, [U]はユニタリ行列であり, 各列は出力の正規直交基底 で構成される。また, [V]もユニタリ行列であり, その各列は入力 の正規直交基底を示す。[ $[\Sigma]$ は特異值を対角項にもつ特異值行列を有 する。

なお, この特異值は分解前の行列のランクの数だけ得られ, 特異 值の大きさは各モードの寄与度の大きさを表している。

ここで，特異值が 0 もしくは比較的小さなモードは無視して， N' 次のモードまでを考慮するものとして, 各部分行列を縮退させる。 なお, 部分行列は縮退するが全体としての影響係数マトリクスの次 元は変わらない。

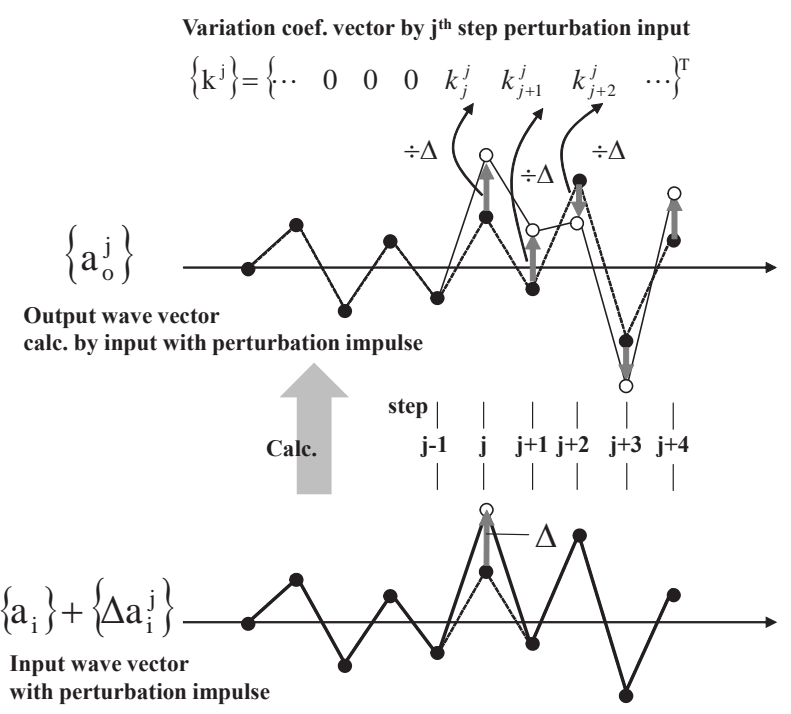

Fig. 5 Response by perturbation impulse input at time step j

$$
\underset{N \times N}{[K}]=\underset{N \times N^{\prime} N^{\prime} \times N^{\prime} N^{\prime} \times N}{\left[U^{\prime}\right]\left[\sum^{\prime}\right]\left[V^{\prime}\right]}
$$

このように特異值の小さなモードを無視するのは，特異值が 0 も しくは小さなモードを考慮した状態で逆行列を算定すると, 同定さ れた地震動に特異值（影響度）の小さいモードの成分が多く含まれ てしまうためである。また，数值計算上の 0 に近い值での除算等が 生じ，多くの数值誤差が入ることを避ける意味合いもある。

前述したように, 本手法はあくまで近似解法であり反復によって 誤差を小さくしていく手法であるため, 微小なモードは無視し, 有 意なモードを選択して修正を行うこととする（これは高次の項を無 視し，低次の項のみを用いたモーダルアナリシス 13）と考え方は同 じである)。なお, 選別する特異值の境界值は, 対象とする問題に応 じて適宜設定する必要がある。今回の例題では特異值は「各モード の増幅倍率」に相当するため,「1 以上」など工学的に有意な増幅率 を設定することが考えられるが，低次モードによる修正だけでは， 要求される許容誤差以内に収まらない可能性がある。そのような場 合には，反復回数に応じて徐々に閾值を下げ，より多くのモードを 用いて修正を行うことが必要になる。

(12)式から, 各行列のユニタリ性, 対角性を利用して, [K]の一般 化逆行列 $[K]^{+}$は下式によって求めることができる。

$$
\underset{N \times N}{[K}]^{+}=\left[\underset{N \times N^{\prime}}{V_{N^{\prime} \times N^{\prime}}^{\prime}}\right] \underset{N^{\prime} \times N}{\left.\sum_{N^{\prime}}^{\prime}\right]^{-1}}\left[\underset{U^{\prime}}{T}\right.
$$

\section{(d) 入力地震動の補正}

(4)式で求めた現候補入力地震動の出力誤差と, (13)式で求めた一 般化逆行列から入力地震動の補正量を下式によって算定する。

$$
\left\{\Delta \mathrm{a}_{\mathrm{i}}\right\}=\underset{\mathrm{N} \times \mathrm{N}}{[\mathrm{K}]^{+}}\{\mathrm{r}\}
$$

この補正量を, 現候補入力地震動に足しこみ, 新たな候補地震動 $\left\{\mathrm{a}_{\mathrm{i}}\right\}_{\text {new }}$ を作成する。

$$
\left\{a_{i}\right\}_{\text {new }}=\left\{a_{i}\right\}+\left\{\Delta a_{i}\right\}
$$


この候補波を用いて, 式(3)と同様に構造解析を再度実施し, 誤差 が許容範囲内になるまで, (b)〜 (d)の修正を繰り返す。

\section{3. 提案手法の検証}

\section{1 検討概要}

例題を用いて，2 章で提案された手法の精度を確認するとともに 課題を整理する。

Fig.6に解析モデルを示す。解析モデルは深さ $50 \mathrm{~m}$ の柱状の自由 地盤モデルとする。地盤は軟弱な砂地盤を想定し, V s 值は $100 \mathrm{~m} / \mathrm{s}$, ポアソン比は 0.33 , 単位体積重量は $1.8 \mathrm{t} / \mathrm{m}^{3}$ とする。地盤の非線形特

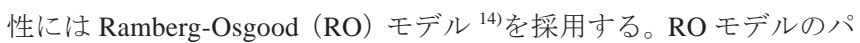
ラメータは, 文献 15 に記載された砂質土の值を参照し，せん断剛性 低下率 $\left(\mathrm{G} / \mathrm{G}_{0}\right)$ が $50 \%$ となるときのせん断ひずみ $\gamma_{0.5}=0.10 \%$, 最大減 衰定数 $h_{\max }=0.21$ となるように設定する。

地盤下部は, 粘性境界とし, Vs 值は $300 \mathrm{~m} / \mathrm{s}$, 単位体積重量は $1.8 \mathrm{t} / \mathrm{m}^{3}$ に相当する粘性ダンパーを，下式によって設定している。なお， $\rho$ は基盤の単位体積重量, A は土柱モデルの断面積である。

$$
\mathrm{C}=\rho \cdot \mathrm{Vs} \cdot A
$$

時間積分には New mark- $\beta$ 法 $(\beta=1 / 4)$ を用い, 解析時間刻みは 0.01 秒とする。解析プログラムには自社開発プログラム M UDIAN ${ }^{16)}$ を用 いる。

この解析モデルに対して, Fig.7 に示すTaft1952EW 地震動（最大 加速度 $1.76 \mathrm{~m} / \mathrm{s}^{2}$ ，継続時間 10 秒まで）を $\alpha$ 倍（ $\alpha=1,2,3 ）$ したものを 入力地震動とする応答解析を実施し, 地表面出力を算出する。解析 時間については, 最も大きな 3 倍入力の場合で約 3 秒であった。

Fig.8 には算定された地盤の最大応答加速度, 最大変位, 最大せん 断ひずみの分布図を示す。図より, 地盤の最大せん断ひずみは 1 倍 入力の場合でも $0.1 \%$ 以上達しており非線形化が生じていること がわかる。また， 3 倍入力の場合においては，さらにひずみが増大 し， $-30 \mathrm{~m}$ 以深においては $1 \%$ 以上のせん断ひずみが生じており，加 速度分布や変位分布が単純な係数倍の応答となっていないことから 非線形領域に達していると判断できる。Fig.9 には, 入力地震動と地 表面応答の加速度時刻歴の伝達関数を, ParzenWindow(Window 幅 $0.1 \mathrm{~Hz}$ )によって平滑化して示す。図より, 入力地震動が大きくなる につれて, 非線形化の影響により全周期帯に渡って伝達関数が变化 していることが確認できる。

これらの解析から得られた地表面加速度時刻歴を再現する入力地 震動が提案手法によって算定できるか，また算定された入力地震動 は，この解析に用いた地震動とどの程度一致するのかを確認する。

式(5)で設定する許容誤差は設定せず, 繰り返し回数は 100 回で打 ち切りとし，式(8)で設定する摂動量については $0.01 \mathrm{~m} / \mathrm{s}^{2}$ とた。ま た, 式(12)で設定するモードの数については, 初期のイテレーショ ンでは「特異值 1 以上」のモードを抽出することとし, 以降, 式(14) の加速度修正ベクトルの成分の最大值が $0.5 \mathrm{~m} / \mathrm{s}^{2}$ 未満になった時点 で，特異值の閾值を半分にしていく。これにより徐々に高次のモー ドを含んだ修正を行うようにしている。なお, 初期の闇值である「特 異值 1 以上」とは各モードの入出力波形のノルムの増幅率が 1 以上, すなわちノルムが増幅するモードを抽出することに相当する。

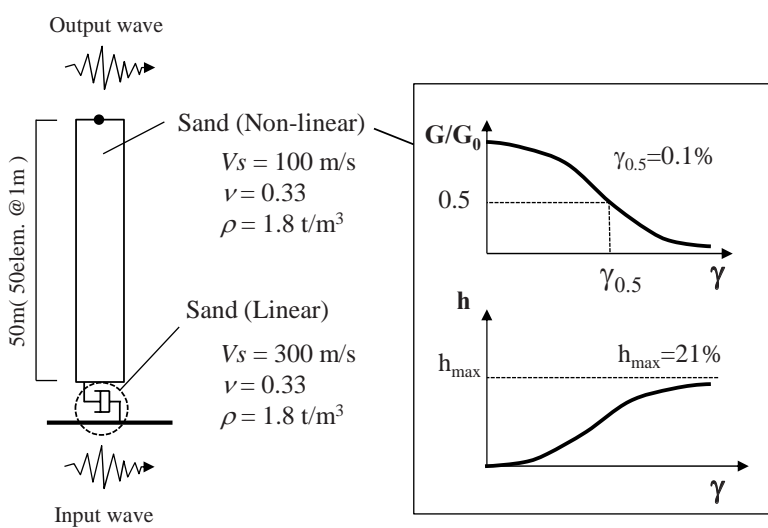

Fig.6 Analysis model

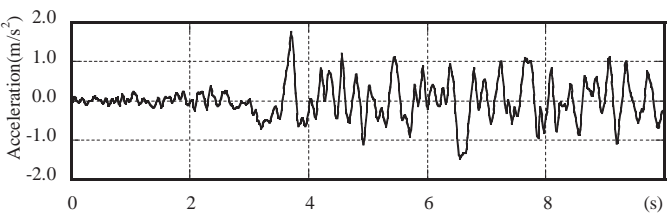

(a) Time history

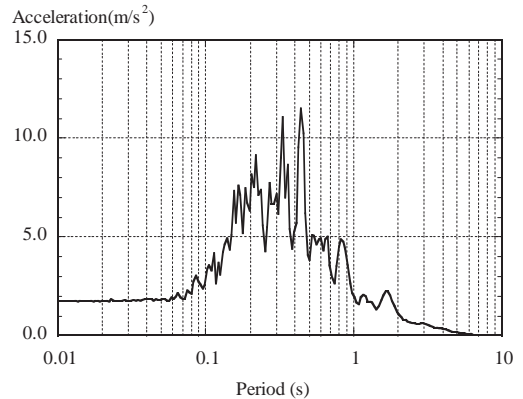

(b) A cc. R esponse Spectrum ( $h=1 \%$ )

Fig.7 Input Motion (Taft1952EW)
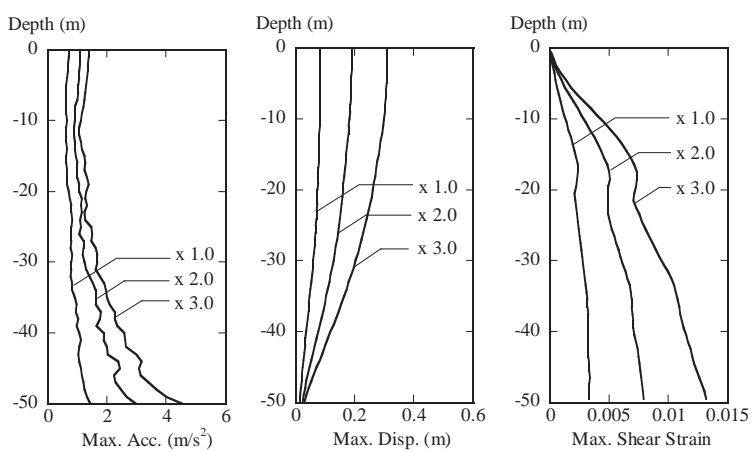

Fig.8 Maximum Response Value (Taft1952EW) Transfer fanction (Abs.)

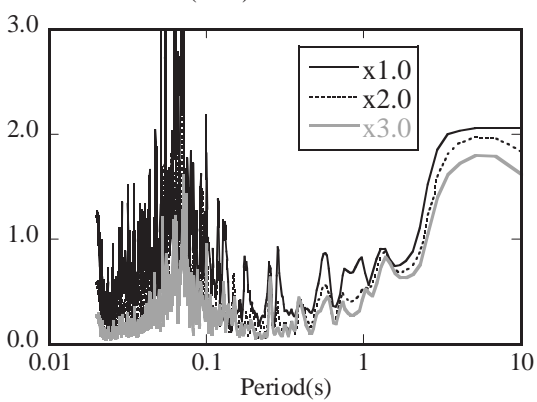

Fig.9 Transfer Function (Output/Input) 


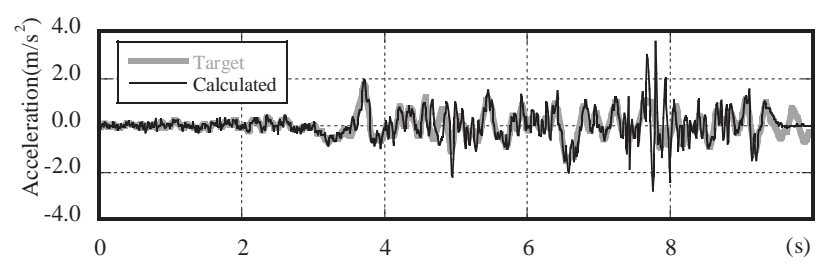

(a) $\alpha=1.0$ (Iteration $=20$ )

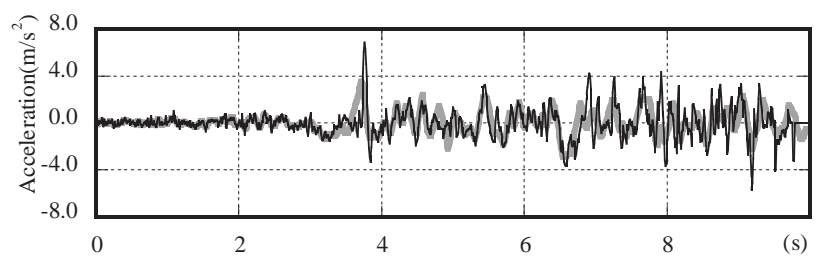

(b) $\alpha=2.0$ (Iteration $=70$ )

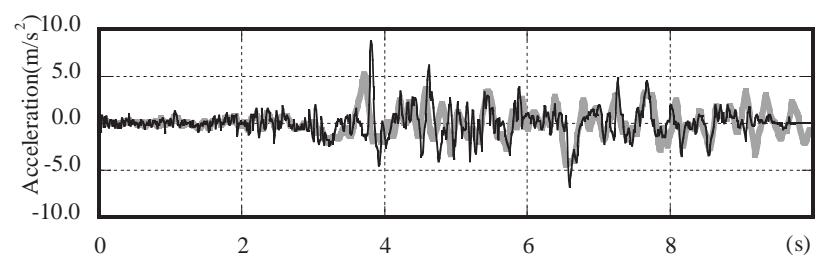

(c) $\alpha=3.0$ (Iteration $=60$ )

Fig.10 Identified input motion

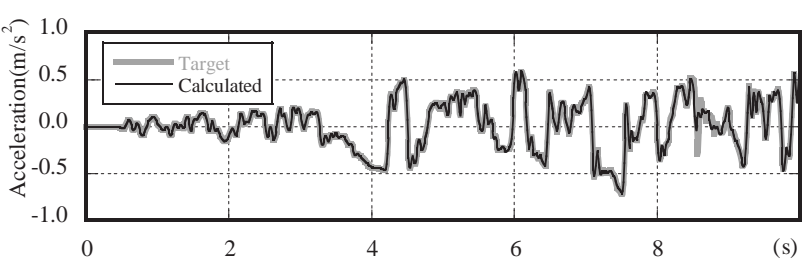

(a) $\alpha=1.0$ (Iteration $=20$ )

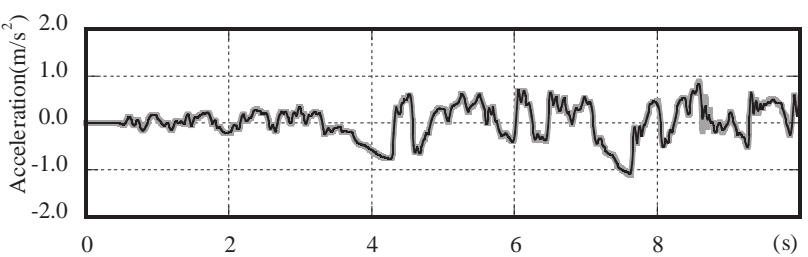

(b) $\alpha=2.0$ (Iteration $=70$ )

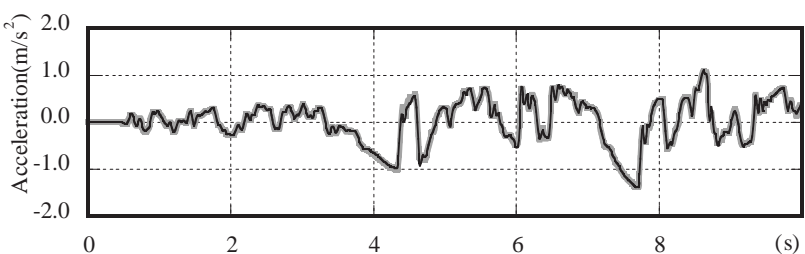

(c) $\alpha=3.0$ (Iteration $=60$ )

Fig.11 Output motion calculated with identified input motion

Table2 Calculation Cost of Identification

\begin{tabular}{|c|c|c|c|}
\hline Coefficient of input motion $\alpha$ & 1.0 & 2.0 & 3.0 \\
\hline Number of Iteration for Convergence (times) & 11 & 69 & 56 \\
\hline Calculation Time (h) & 9.7 & 65.7 & 53.9 \\
\hline
\end{tabular}

\section{2 検討結果}

Fig.10，11 にターゲットとする地表面出力から同定された入力地 震動およびその入力地震動によって得られる地表面出力の加速度時 刻歴を黒実線で示す。なお，これらの同定結果はターゲットとする 地表面出力との RMS 誤差が概ね 1.0 を下回る場合のケースを抽出し ている。また, 比較のため, 前節の解析で用いた入力地震動および それから得られる地表面出力（ターゲット波）を灰実線で併せて示 す。

図より, いずれの入力倍率においても, 同定された入力地震動に 若干の差はあるものの, 地表面出力はよい精度で一致していること がわかる。このように地表面出力は概ね整合している一方で, 同定 された入力地震動の差が大きい要因は, 2.1 節で述べたようにこの 逆問題が単射問題でないためと考えられる。すなわち, ターゲット とする地表面出力を実現する入力地震動は複数存在し, 一意には定 まらないため, 今回同定された入力地震動も解の一つではあるもの の, 前節で入力地震動として用いた地震動と完全には一致しなかっ たものと考えられる。ただし，いずれの入力倍率においても，初期 の入力が小さく概齐線形とみなせる領域においては, 入力地震動の 波形はよい精度で一致している。これは, 線形状態での入出力関係 は 1 対 1 対応寸るため, 精度良く算定できたものと考えられる。

Table2 には, RMS 誤差を 1.0 未満とするために必要な収斂回数お

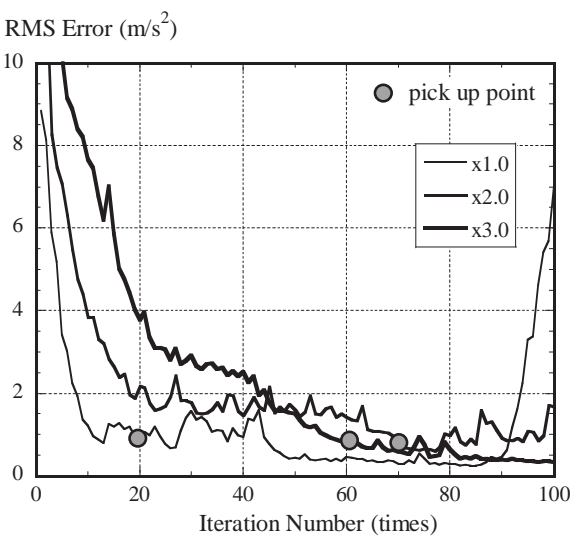

Fig.12 RMS Error

よび計算時間を, Fig.12 には収斂による RMS 誤差の減少の様子を示 す。非線形性の小さな 1 倍入力の場合は収斂が早いが，非線形化が 進む 2 倍入力, 3 倍入力では多くの収斂回数, 収斂時間がかかって いる。非線形化が進んだ解析においては応答が複雑になり，誤差が 収束しにくくなったものと考えられる。

また, 計算コストの最も少ない 1 倍入力の場合であっても, 計算 
時間は 10 時間程度と, 過大な計算時間がかかっている。今回の手法 は, 1 回の修正を行うために, ある 1 時刻に摂動を加えた計算を, 全時間ステップ数分実施する必要があるため, 仮にステップ数が 2 倍になれば, 1 回の計算時間が約 2 倍（非線形化が極端に進まなか った場合）になり, 摂動解析の数も 2 倍になってしまうため, 同定 にかかる時間は短く見積もっても 4 倍以上となってしまう。そのた め, 今回の簡易解析モデルとは異なり, 1 回の解析に時間がかかる 大規模なモデルでの同定や, 継続時間の長い地震動を用いた同定に 適用するのは困難になると予測される。

\section{3 用いるモードの数が収斂性に与える影響}

前述したように, 本提案手法の特徴は反復的な修正を有意なモー ドに限定して行うことにある。しかしながら, 考え方として全ての モードを用いる方法も当然考えられる。そこで, Fig.13 を用いて, 入力 1 倍のケースについて, 考慮するモードの数を変化させた場合 の収束性の違いを確認する。比較するケースは, 前述した特異值の 最小值を徐々に漸減させる場合に加えて, $1.0,10^{-6}$ で固定とした場 合を追記している。前者は, 常に低次のモードのみで修正を行った 場合, 後者はほぼすべてのモードを用いて修正を行った場合に相当 する。図より，全モードを用いた $10^{-6}$ で固定した場合においては， 収斂せず逆に発散してしまっている。一方, 最小值を 1.0 で固定し た低次モードのみでの修正でも, 誤差の収斂は遅く収斂回数を重ね ても誤差は小さくならない。したがって, 提案手法のように, 初め は低次モードで修正し, 誤差が小さくならなくなる場合には徐々に 高次のモードを追加して修正していくという手法が収斂速度の点で 有効といえる。

なお, この徐々に高次のモードを追加していく手法の場合, 入力 1 倍のケースにおいて, イテレーション 85 回目程度から, 誤差が上 昇している。これは, 徐々に高次のモードを追加していった結果, 解を発散させるような高次のモード, すなわち増幅率のごく小さな モードまでを考慮して修正を行ってしまったためであると考えられ る。Fig.14には, 同ケースの特異值の閾值の変遷を示す。 85 回目付 近で閾值が 0.01 を下回ると, 収束せずに発散に転じており, 今回の ケースでは, 特異值 0.01 未満の高次モードが収束性を阻害している と考えられる。

ただし，この值はあくまで今回のケースに限った值であり，異な るモデルにおいては, 適切な值は異なると考えられる。そのため, 閾值を固定にして適切な閾值を探索するよりは, 今回のように閾值 を漸減させて, 発散に転じる直前の候補波を用いる方法が実用的で あると考えられる。

\section{4. まとめ}

本研究においては, 非線形地盤モデル上の任意の 1 点において指 定された波形を再現するための, 入力地震動を設定する手法を提案 した。提案手法は, システム同定の一手法であるインパルス応答マ トリクスの特異值分解を用いて, 有意なモード形状を選択し反復的 に誤差を修正していくことを特徴とする手法（MIEC 法）である。

まず, 提案したMIEC 法を用いたインバージョンのフローおよび 計算手順について説明し, つづいて, 例題を用いて提案手法の精度 検証を行った。得られた知見を以下に示す。

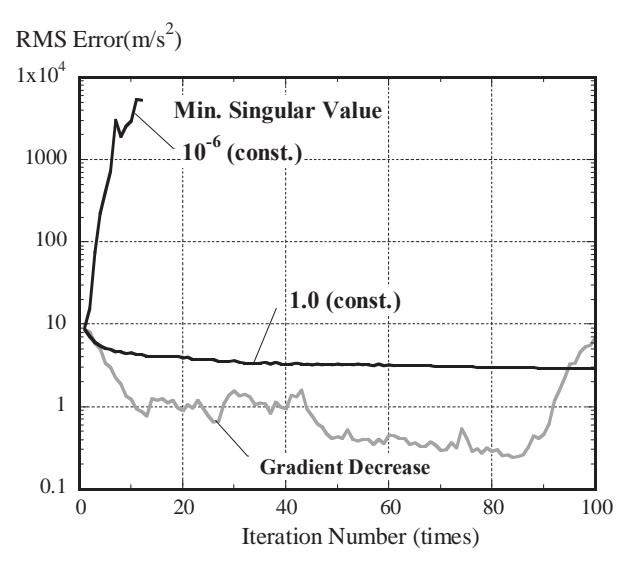

Fig.13 Effect of Minimum Singular Value on Convergence

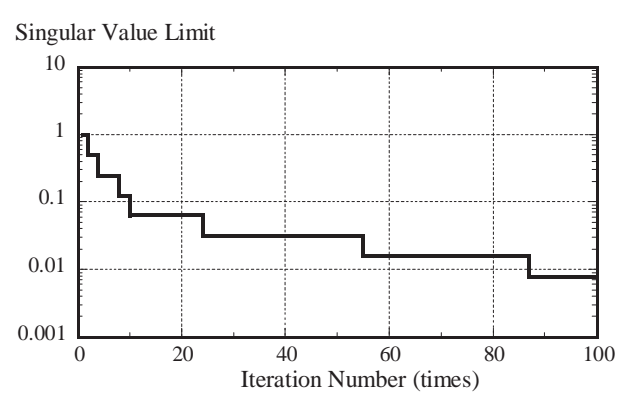

Fig.14 Singular Value Limit

1) 入力地震動に摂動を与えた場合の影響係数マトリクスを算出し, その一般化逆行列の有意なモードを選択的に利用して, 反復法に よる収斂計算を行うことで, 入力地震動のインバージョンを行う 手法を提案した。

2) 例題を用いて, 提案手法により, 非線形地盤モデルの地表面応答 を再現させる入力地震動を算定できることを確認できた。ただし， 選択するモードの設定によっては, 収束しない場合があり注意が 必要である。

3) 今回実施した簡便モデルにおいても同定には多くの計算時間が必 要であった。より地震動の継続時間が長い場合や，1回の解析に 多くの時間が必要なモデルを用いる場合に適用が困難になること が䯚念される。

以上のように, 今回提案した手法は, これまで実施が困難であっ た非線形地盤モデルのインバージョン手法として有効であることが 確認できた。一方, 選択するモードの設定によっては収束しない場 合があるほか，大規模モデルへの適用は算出に多くの計算コストが 必要となることが予測されるため現時点では現実的な手法とは言い 難い。今後は, より汎用的な手法とするべく, 選択するモードの合 理的な設定方法や, より高速なインバージョンを行える方法につい て更なる研究を進めていきたい。 
参考文献

1) Sakai, M. et al: Simulation A nalysis of a Super High-Rise RC Building Using Moment-Resisting Frame System Including Pile Group and Surrounding Soil and Seismic Performance Evaluation for Future Scenario Earthquake, Journal of Structural and Construction Engineering (Transactions of $\mathrm{AlJ}$ ), Vol.82, No.732, pp.171-181, 2017.2(in J apanese)

酒井美月ほか 5 名 : 建物・杭・地盤の一体モデルによる超高層 R C 造建 物のシミュレーション解析及び想定地震時の耐震性能評価, 日本建築学 会構造系論文集，Vol.82，No.732，pp.171-181，2017.2

2) Kaneko, 0. et al: ANALYTICAL STUDY ON DAMAGE FACTOR OF PILE FOUNDATIONS DURING THE 2011 OFF THE PACIFIC COAST OF TOHOKU EARTHQUAKE, Journal of Structural and Construction Engineering (Transactions of AlJ), Vol.80, No.717, pp.1699-1706, 2015.11(in Japanese)

金子治ほか 4 名：東北地方太平洋沖地震における杭基礎の被害要因に関 する解析的検討, 日本建築学会構造系論文集, V ol.80, N o.717, pp.1699-1706, 2015.11

3) Schnabel P. B., Lysmer J. and Seed, H.B.: SHAKE - A Computer Program for Earthquake response analysis of horizontally layered sites, EERC Report, V ol.72, N o.12, U niversity of California, Berkley, 1972

4) Dan, K.: Simulation of Soil and Structure Interaction Observed in the Earthquake Motions at the Kushiro District Meteorological Observatory, Journal of Structural and Construction Engineering (Transactions of $\mathrm{AlJ}$ ), N 0.470, pp.75-84,1995.4(in Japanese)

壇一男: 釧路地方気象台の地震記録に見られる地盤と建物の相互作用効 果およびそのシミュレーション, 日本建築学会構造系論文集, N 0.470 , pp.75-84, 1995.4

5) Ott. N. and Meder, H. G.: Kalman filter as a Prediction Error Filterm, Geophysical Prospecting 20, pp.549-560, 1970

6) Toki, K., Sato, T. and Kiyono, J. : Identification of structural parameters and input ground motion from response time histories, Proc. of the Japan Society of Civil Engineers, No.410, pp.243-251, 1989

7) Sutoh, A and Hoshiya, M :: Back A nalysis by Finite Element M ethod using EK-WLI Procedure, J. of J apan Society of Civil Engineers, V ol.1992, N 0.446 , pp.177-185, 1992(in Japanese)

須藤敦史, 星谷勝: EK-WLI 法と有限要素法を用いた逆解析, 土木学会 論文集，V Vol.1992, N o.446, pp. 177-185， 1992
8) Sutoh, A. et al: Identification of a Input and Parameters of a M DOF System, J. of Structural Engineering, V ol.41A, pp.709-716, 1995(in Japanese) 須藤敦史ほか 2 名: 絶対応答を用いた地震動入力とシステムパラメータ 同定，構造工学論文集，Vol.41A，pp.709-716， 1995

9) Maruyama, M and Hoshiya, M.: KOUZOUKEINI TAISURU NYUURYOKU JISHINDOUNO DOUTEI, Proc. of JSCE Earthquake Engineering Symposium, No.19, pp.145-148, 1987(in Japanese)

丸山収, 星谷勝 : 構造系に対する入力地震動の同定, 地震工学研究発表 会講演概要, No.19, pp.145-148, 1987

10) Sakai, H. et al: A Basic Study to Identify the Incident Seismic Wave on the Base Layer in Time Domain, J. of J apan Society of Civil Engineers, V ol.1997, No.577, pp.53-64, 1997.10(in Japanese) 酒井久和ほか 2 名 : 時間領域での基盤入力地震動の推定法に関する基礎 的研究, 土木学会論文集, Vol.1997, N 0.577, pp.53-64, 1997.10

11) Adachi, S.: MATLAB NIYORU SEIGYONOTAMENO JOKYUSISUTEMU DOUTEI, TDU Press, 2004

足立修一：MATLAB による制御のための上級システム同定, 東京電機大 学出版会, 2004

12) Owen, D. R. J. and Hinton E.: Finite Elements in Plasticity - Theory and Practice, Pineridge Press Limited, 1980

13) Shibata, M.: SAISHINTAISHINKOUZOUKAISEKI, 3rd Edition, Morikita, 2002(in Japanese) 柴田明徳：最新耐震構造解析（第 3 版），森北出版， 2002

14) Jennnings, P. C.: Periodic Response of General Yielding Structure, J. Eng. Mech. Div., A SCE, EM 2, pp.131-163, 1964

15) Architectural Institute of Japan: Seismic Response Analysis and Design of Buildings Considering Dynamic Soil-Structure Interaction, M aruzen, 2006(in Japanese)

日本建築学会 : 建物と地盤の相互作用を考慮した応答解析と耐震設計, 丸善, 2006

16) Shiomi, T. et al: Structural analysis system considering non-linear behavior of soils, Takenaka Technical Research Report, N o.54, pp.1-8, 1998(in J apanese) 塩見忠彦ほか 3 名: 地盤の非線形挙動を考慮した構造解析システムの開 発, 竹中技術研究所報告, N o.54, pp.1-8, 1998 


\section{INPUT MOTION INVERSION IN ELASTO-PLASTIC SOIL MODEL BY USING MODAL ITERATIVE ERROR CORRECTION METHOD}

\section{Takuya SUZUKI*1}

${ }^{* 1}$ Chief Researcher, R\&D Institute, Takenaka Corporation, Dr.Eng.

Simulation analysis is an effective method for the safety assessment of a building after an earthquake. This kind of analysis is effective for evaluating foundations or piles, whose safety cannot be confirmed by visual check.

In conducting these analyses, an input motion should be set to reproduce an observed wave at an observed point of the analysis model. If the analysis model is in a linear range, the input motion can easily be set using the frequency domain method, which is the most popular method. However, this setting is difficult if the analysis model (e.g., soil) exhibits non-linear behavior. In these cases, the properties of the analysis model changes at every time step. Therefore, the frequency domain method cannot be applied. Instead, the time domain method must be applied, but no effective inversion method of the time domain is available.

This study proposes a new time domain inversion method. First, the method outline and details are described. Second, the method precision is confirmed through experimentation. Thus, a new method for an input motion inversion in a non-linear soil model is presented.

Followings are a summary of the study findings:

(1) This study proposes a new time domain inversion method with a generalized inverse of the perturbation impulse matrix and the iterative method. In proposed method, first, effects of perturbation impulse inputs are calculated. Secondly, "perturbation impulse matrix" is made from these effect vectors. Then, from singular value decomposition of perturbation impulse matrix, general inverse of the perturbation impulse matrix composed by main modes is made. Using this inverse, input correction amount is calculated. And then these corrections repeated until error become small enough.

(2) Through a sample problem, the accuracy of this proposed method is confirmed. Then, it is confirmed that an identified input motion reproduce a target output motion in surface of elasto-plastic soil model.

The findings of this study confirm the applicability of this proposed method for inversion. There is, however, the need for further improvement of the procedure because it is difficult to select effective modes. Moreover, much calculation time that this method need is important an important issue.

(2018 年 1 月 31 日原稿受理, 2018 年 4 月 2 日採用決定) 